\title{
Stimulus-specific Deactivation of Chemotactic Factor-induced Cyclic AMP Response and Superoxide Generation by Human Neutrophils
}

\author{
Louis Simchowitz, John P. Atkinson, and Isaias Spilberg, Department of Medicine \\ and Division of Rheumatology, John Cochran Veterans Administration Medical \\ Center, Washington University School of Medicine, and Howard Hughes Medical \\ Institute Research Laboratories, St. Louis, Missouri 63110
}

\begin{abstract}
A B S TRACT The responses of isolated human peripheral neutrophils to either simultaneous or sequential additions of two chemotactic factors were studied. Simultaneous additions of formyl-methionylleucyl-phenylalanine $(10-100 \mathrm{nM})$ and the fifth component of complement, C5a $(1-10 \mu \mathrm{l} / \mathrm{ml})$, evoked partially additive responses of membrane depolarization as measured by the fluorescent dye 3,3'-dipropyl-thiocarbocyanine, a transient elevation of intracellular cyclic AMP (cAMP), and superoxide $\left(\mathrm{O}_{2}^{-}\right)$generation as assessed by ferricytochrome $c$ reduction. Preincubation of the cells with either formyl-methionyl-leucylphenylalanine or C5a alone caused dose-dependent inhibition of the depolarization, the cAMP increase, and $\mathrm{O}_{2}^{-}$release induced by a subsequent exposure to an optimal dose of the same stimulus, i.e., deactivation occurred. In contrast, when cells were treated with one chemotactic factor and then exposed to the other stimulus, the cells exhibited a normal response of peak depolarization, the rise in cAMP, and $\mathrm{O}_{2}^{-}$production i.e., cross-deactivation failed to occur. The results imply that deactivation of these phenomena is stimulus specific. Further, these observations are consistent with the hypothesis that cross-deactivation of chemotaxis is mediated by one or more processes that are irrelevant to $\mathrm{O}_{2}^{-}$generation, and that occur distal to the depolarization and cAMP steps in the sequence of neutrophil activation: possibly microtubule polymerization and orientation.
\end{abstract}

\section{INTRODUCTION}

The exposure of neutrophils to a chemotactic factor, in the absence of a gradient, has been shown to prevent the cells from responding with directional migration

Received for publication 14 January 1980 and in revised form 16 May 1980. when they are challenged with the same or a different chemotactic factor after washing (1-3). These two processes have been termed deactivation and cross-deactivation, respectively. Inasmuch as motility per se is not affected (4), it seems likely that an understanding of the deactivation phenomena will add considerably to our knowledge of the specific chemotactic process. That structurally unrelated chemotactic factors, some of which clearly bind to distinct cell receptors $(5,6)$, can cross-deactivate the chemotactic response indicates that cross-deactivation cannot possibly be explained as simply the effect of receptor blockade, although deactivation could. Our work explores this idea by studying the early cellular events occurring in response to sequential exposures of human peripheral neutrophils to the tripeptide $n$-formyl-methionyl-leucyl-phenylalanine (FMLP), ${ }^{1}$ and to a partially purified preparation of the fifth component of complement, C5a. The chemotactic factor-induced responses measured were membrane potential alterations as measured by a fluorescent cyanine dye, transient elevations in intracellular levels of cyclic AMP (cAMP), and $\mathrm{O}_{2}^{-}$generation as assessed by ferricytochrome $c$ reduction. The results indicate that deactivation of these three functions is stimulus specific and that a phenomenon analogous to cross-deactivation does not exist for the chemotactic factor-induced cAMP response or for $\mathrm{O}_{2}^{-}$release.

\section{METHODS}

Medium. The medium used in this study was prepared with deionized water as a modified Hanks' balanced salt solution, supplemented with $1 \mathrm{mg} / \mathrm{ml}$ bovine serum albumin, pH 7.40.

Neutrophils. Human peripheral neutrophils were isolated by sequential dextran sedimentation and Ficoll-Hy-

${ }^{1}$ Abbreviations used in this paper: FMLP, formyl-methionyl-leucyl-phenylalanine; DMSO, dimethyl sulfoxide. 
pacque gradient centrifugation (Pharmacia Fine Chemicals, Div. of Pharmacia, Inc., Piscataway, N. J.) (7). Contaminating erythrocytes were lysed by treatment with ammonium chloride (Fisher Scientific Co., Pittsburgh, Pa.) for $10 \mathrm{~min}$ at $37^{\circ} \mathrm{C}$. The neutrophils were washed three times, then resuspended in medium and counted. The purity of the neutrophil suspensions averaged $96 \%$ as judged by Wright's stain. Viability averaged $96 \%$ as assessed by eosin Y exclusion. At the concentrations employed in this study, none of the agents tested affected neutrophil viability.

Chemotactic factors. FMLP was purchased from Sigma Chemical Company, St. Louis, Mo. FMLP was dissolved at $1 \mathrm{mM}$ in dimethyl sulfoxide (DMSO, Fisher Scientific) and stored at $-70^{\circ} \mathrm{C}$. F.MLP was diluted in medium before each experiment. Though no effects could be detected with $0.1 \%$ or less DMSO in any of the assays employed, controls contained the appropriate amounts of DMSO.

A partially purified C.5a fraction was prepared as previously described by Fantone et al. (8). Briefly, fresh human serum was treated with $10 \mathrm{mg} / \mathrm{ml}$ zymosan (Sigma Chemical Co.) in the presence of epsilon-aminocaproic acid $(1.0 \mathrm{M})$ for $90 \mathrm{~min}$ at $37^{\circ} \mathrm{C}$. After removal of the zymosan particles by centrifugation, the zymosan-treated serum was chromatographed on a Sephadex G-100 column (Pharmacia Fine Chemicals), using

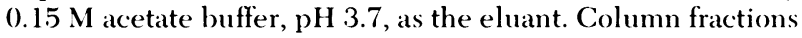
were pooled and stored at $-70^{\circ} \mathrm{C}$. Concentrations are expressed as microliters of stock solution per milliliter of reaction mixture and referred to as $\mathrm{C} 5 \mathrm{a}$, despite that some C.5 a des Arg and perhaps other C.5 fragments might still be present in the preparation.

Experimental design. To test the ability of FMLP and C.5a to deactivate or cross-deactivate the cellular responses, experiments were initially performed in two ways. In method 1, cells were exposed to one stimulus, pelleted, washed once, and then resuspended in medium containing the same or alternate stimulus. In method 2 , after pretreatment with one stimulus, the cells were challenged with the same or alternate stimulus without pelleting and without an intervening wash between successive challenges. There were no differences in the subsequent responses to a second challenge with the same or different stimulus in either of the two methods. Therefore, unless otherwise stated, all experiments were performed using method 2.

Assay of superoxide radical generation. Superoxide generation was measured by ferricytochrome $c$ (type III, Sigma Chemical Co.) reduction as previously described (9). All experiments were performed in duplicate in a volume of $0.6 \mathrm{ml}$ in plastic microcentrifuge tubes (Beckman Instruments Inc., Fullerton, Calif.) containing FMLP and/or C.5a dilution, ferricytochrome $c$ solution (75 $\mu \mathrm{M}$ final concentration), and neutrophils $\left(1.5-3.0 \times 10^{6} / \mathrm{ml}\right)$. Tubes were then placed in a $37^{\circ} \mathrm{C}$ water bath and periodically agitated. After $5 \mathrm{~min}$, the tubes were removed and the reactions stopped by pelleting the cells by centrifugation at $8,000 \mathrm{~g}$ for $30 \mathrm{~s}$ in a microcentrifuge (Microfuge B, Beckman Instruments Inc.); the supernates were decanted.

For experiments in which FMLP and C5a were tested for their ability to deactivate and cross-deactivate the generation of $\mathrm{O}_{2}^{-}$, neutrophils were first exposed to one stimulus for 5 min at $37^{\circ} \mathrm{C}$ in the presence (Tables I and II, part A) or absence (Tables I and II, parts B, C, and D) of ferricytochrome $c$. After the 5-min preincubation, set $A$ was centrifuged and the supernates analyzed. At the same time, the second stimulus (FMLP, C5a, or medium) was added to sets B, C, and D, respectively, together with the ferricytochrome $c$ solution, and the cells were incubated for an additional $5 \mathrm{~min}$ at $37^{\circ} \mathrm{C}$. The presence (part A) or absence (parts B, C, and D) of ferricytochrome $c$ during the first stimulation had no effect on the sub- sequent cellular response to the second challenge with either chemotactic factor.

The amount of reduced cytochrome $c$ in the supernates was assayed as follows: $0.2 \mathrm{ml}$ of supernate was added to $2.8 \mathrm{ml}$ of $0.1 \mathrm{M}$ potassium phosphate buffer, $\mathrm{pH} 7.40$, and the absorbance spectrum measured at $5.50 \mathrm{~nm}$ in a Gilford 250 spectrophotometer (Gilford Instrument Laboratories Inc., Oberlin, Ohio). Using potassium ferricyanide (Fisher Scientific Co.) and sodium dithionite (J. T. Baker Chemical Co., Phillipsburgh, N. J.), the amount of reduced (ytochrome $c$ and the total amount of cytochrome $c$ present were calculated using an extinction coefficient of $21.1 \mathrm{mM}^{-1}$ at $550 \mathrm{~nm}$ (reduced-oxidized) (10). The addition of $10 \mu \mathrm{g} / \mathrm{ml}$ superoxide dismutase (Sigma Chemical Co.) to the complete reaction mixtures inhibited both FMLP- and C.5a-induced cytochrome $c$ reduction by $>90 \%$, indicating that the reaction was specific for $\mathrm{O}_{2}^{-}$. Superoxide generation is expressed as nanomoles of ferricytochrome $c$ reduced per $10^{6}$ neutrophils.

Radioimmunoassay of cAMP. Experiments were performed at $37^{\circ} \mathrm{C}$ in $13 \times 10()-\mathrm{mm}$ glass tubes (Fisher Scientific) in a total volume of $0.4 \mathrm{ml}$, containing $10^{7}$ neutrophils. The stimuli, FMLP and C.5a, were pipetted singly or in combination, followed by the addition of the neutrophil suspensions. At stated times, the incubations were terminated by boiling for $2 \mathrm{~s}$ in a Bunsen burner flame, as previously described (11, 12). For experiments in which FMLP and C.5a were tested for their ability to deactivate and cross-deactivate the cellular response to a second stimulus, the neutrophils were first exposed to one stimulus for $5 \mathrm{~min}$ at $37^{\circ} \mathrm{C}$, during which the CAMP responses were measured. The second stimulus was then added and the cells incubated for an additional $5 \mathrm{~min}$ at $37^{\circ} \mathrm{C}$. Following sonication and centrifugation of the reaction mixtures at $2,600 \mathrm{~g}$ for $10 \mathrm{~min}$, the supernates were separated and acetylated with $0.003 \mathrm{ml}$ of a freshly prepared $2: 1 \mathrm{mix}$ ture of triethylamine (Eastman Kodak Co., Rochester, N. Y.) and acetic anhydride (Fisher Scientific) according to the procedure of Harper and Brooker (13). 50- $\mu$ l aliquots of this mixture were then diluted with $0.05 \mathrm{M}$ sodium acetate buffer $(\mathrm{pH} 6.2)$ and radioimmunoassays for cAMP and cGMP were performed as described by Steiner et al. (14). Greater than $90 \%$ of the CAMP reactivity was destroyed by treatment with beef heart phosphodiesterase (Sigma Chemical Co.). The methods of cyclic nucleotide extraction and radioimmunoassay procedures have been previously described in detail (15).

Fluorescence measurements. The fluorescent dye 3,3'-dipropylthiocarbocyanine iodide was a gift of Dr. Alan Waggoner of Amherst College, Amherst, Mass. A stock solution of the dye $(1 \mathrm{mM})$ was prepared in ethanol and stored at $4^{\circ} \mathrm{C}$, protected from light.

Studies were performed in a Turner Model 430 spectrofluorometer (Turner Associates, Div. of American Sterilizer Co., Palo Alto, Calif.) in which the temperature of the samples and cuvette compartment were maintained at $37^{\circ} \mathrm{C}$ by continuously circulating warm water. Excitation was at $622 \mathrm{~nm}$ and emission at $670 \mathrm{~nm}$. Experiments were performed in a total volume of $3 \mathrm{ml}$, containing $4 \times 10^{6}$ neutrophils. The dye was added ( $3 \mu \mathrm{l}$ of stock solution in ethanol) giving a final concentration of $1 \mu \mathrm{M}$ and $0.1 \%$ ethanol. The cells were equilibrated with dye for $5-10 \mathrm{~min}$ at $37^{\circ} \mathrm{C}$ before taking measurements. When a stable base line of fluorescence was attained, FMLP and/or C5a as concentrated stock solutions in medium were added and the changes in fluorescence monitored continuously for at least $5 \mathrm{~min}$ at $37^{\circ} \mathrm{C}$. In the absence of cells, neither FMLP nor C5a affected dye fluorescence. Fluorescence data are reported in arbitrary fluorescence units, a change of $10 \mathrm{U}$ representing $\sim 20 \%$ change in total fluorescence. Data are also reported as $\Delta$ fluorescence units, the peak fluorescence obtained in the presence of FMLP 
minus the fluorescence of control cells in medium. At the concentrations used, neither ethanol nor the dye affected neutrophil viability as assessed by eosin Y exclusion. The addition of dye $(1 \mu \mathrm{M})$ to the cells had no significant effect on the functional integrity of the cells as assessed by the magnitude of superoxide generation induced by $100 \mathrm{nM}$ FMLP in 5 $\min$ at $37^{\circ} \mathrm{C}$.

Experiments were performed to test the effect of preincubation with one stimulus on the subsequent response to the same or a different stimulus. After equilibration with dye, the neutrophils were stimulated with FMLP or C5a and the fluorescence changes monitored continuously for $5 \mathrm{~min}$ at $37^{\circ} \mathrm{C}$. Then, optimal doses of either FMLP $(100 \mathrm{nM})$ or C5a $(10 \mu \mathrm{l} /$ $\mathrm{ml}$ ) were added and the subsequent fluorescence responses recorded for an additional $5 \mathrm{~min}$.

Statistical analysis. Two-tailed comparisons were performed using multiple independent $t$ tests on difference scores (16).

\section{RESULTS}

As previously reported (17), the dose-response ranges of the two stimuli for both $\mathrm{O}_{2}^{-}$release and the cAMP response were the same: FMLP, $10-100 \mathrm{nM}$, and C5a, $1-10 \mu \mathrm{l} / \mathrm{ml}$. Superoptimal doses, i.e., $1 \mu \mathrm{M}$ FMLP and $33 \mu \mathrm{l} / \mathrm{ml} \mathrm{C5a}$ induced responses equivalent to those of $100 \mathrm{nM}$ FMLP and $10 \mu \mathrm{l} / \mathrm{ml} \mathrm{C5a}$, respectively, which therefore represented the optimal doses. These latter concentrations also evoked maximal fluorescence changes in the dye studies (see below).

Effect of simultaneous additions of FMLP and C5a on superoxide generation. Fig. 1 displays the results of four experiments to test the effects of two stimuli, FMLP and $\mathrm{C} 5 \mathrm{a}$, when added together, on $\mathrm{O}_{2}^{-}$production over $5 \mathrm{~min}$ at $37^{\circ} \mathrm{C}$. As previously reported, $\mathrm{O}_{2}^{-}$ release induced by FMLP was complete by $5 \mathrm{~min}$, as was most of the C5a-stimulated $\mathrm{O}_{2}^{-}$generation (17). When FMLP and C5a were added separately, $\mathrm{O}_{2}^{-}$production induced over the concentration range 10-100 $\mathrm{nM} F \mathrm{FLP}$ and $1-10 \mu \mathrm{l} / \mathrm{ml} \mathrm{C5a}$ was significantly greater than medium ( $P$ vs. control $<0.05$ ). Over these dose ranges, the simultaneous additions of FMLP and C5a caused a greater amount of $\mathrm{O}_{2}^{-}$release than either stimulus alone $(P<0.02)$.

In several experiments, the cells were treated with either $400 \mathrm{nM}$ FMLP or $33 \mu \mathrm{l} / \mathrm{ml}$ C5a alone. In all instances, the cellular responses were similar to those obtained with either $100 \mathrm{nM}$ FMLP or $10 \mu \mathrm{l} / \mathrm{ml} \mathrm{C5a}$ alone, indicating that the two latter concentrations had produced the maximal response for each individual stimulus. It is therefore unlikely that the observations reported here reflect an approach to saturation of the response by the combination of the two stimuli. The percent increment in $\mathrm{O}_{2}^{-}$generation caused by the combination of the two stimuli appeared to increase with less than optimal doses of FMLP and C5a until the responses were fully additive at $10 \mathrm{nM}$ FMLP and $1 \mu \mathrm{l} /$ $\mathrm{ml} \mathrm{C5a}(P<0.02)$. The combination of two ineffective doses, $4 \mathrm{nM}$ FMLP and $0.33 \mu \mathrm{l} / \mathrm{ml} \mathrm{C5a}$, did not result in any significant response over control levels.

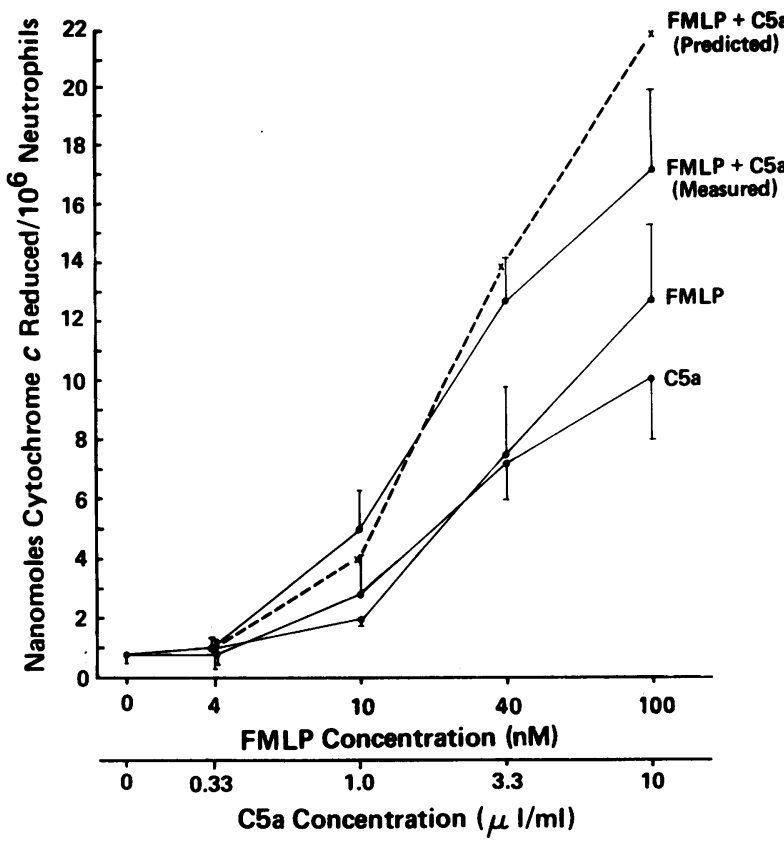

Figure 1 Effect of simultaneous additions of FMLP and C5a on superoxide generation. Neutrophils $\left(1.8-3.0 \times 10^{6}\right)$ were exposed to different concentrations of FMLP and C5a, either separately or together and ferricytochrome $c$ reduction assessed after $5 \mathrm{~min}$ at $37^{\circ} \mathrm{C}$. The increments in the separate FMLP- and C5a-induced $\mathrm{O}_{2}^{-}$release were added to the basal $\mathrm{O}_{2}^{-}$production by control cells to achieve a theoretical plot if the individual FMLP- and C5a-stimulated responses were strictly additive. Results represent the mean \pm SD of four separate experiments each performed in duplicate.

Effect of sequential additions of FMLP and C5a on superoxide generation. The results of experiments designed to test the ability of FMLP preincubation to deactivate or cross-deactivate the neutrophil responses to subsequent challenge with FMLP or C5a, respectively, are shown in Table I. Preincubation of the cells with 4- $100 \mathrm{nM} \mathrm{FMLP}$ for $5 \mathrm{~min}$ at $37^{\circ} \mathrm{C}$ resulted in substantial, dose-dependent inhibition of $\mathrm{O}_{2}^{-}$generation induced by a subsequent challenge with the optimal $100 \mathrm{nM}$ FMLP dose (Table I B). Of note is that $4 \mathrm{nM}$ FMLP, while ineffective in inducing $\mathrm{O}_{2}^{-}$production during the first incubation, significantly inhibited the response to $100 \mathrm{nM}$ FMLP $\left(8.5 \mathrm{vs} .10 .4 \mathrm{nmol} / 10^{6}\right.$ cells, $P<0.05)$. Moreover, for cells initially treated with 4-40 nM FMLP the total increments in $\mathrm{O}_{2}^{-}$generated during the course of the two successive stimulations were significantly less than the sum of the FMLP-induced increments with control cells $(P<0.05)$.

In contrast, FMLP preincubation had no effect on the subsequent response to an optimal $(10 \mu \mathrm{l} / \mathrm{ml})$ dose of C5a (Table I C). FMLP-stimulated $\mathrm{O}_{2}^{-}$release had ceased by $5 \mathrm{~min}$ of incubation (i.e., during the preincubation phase), so that no $\mathrm{O}_{2}^{-}$production above control 
TABLE I

Effect of FMLP Preincubation on Superoxide Generation after Subsequent Challenge with FMLP or C.5a

\begin{tabular}{|c|c|c|c|c|}
\hline $\begin{array}{l}\text { Preincubation } \\
\text { additions }\end{array}$ & $\begin{array}{l}\text { Second } \\
\text { challenge }\end{array}$ & $\mathrm{O}_{2}^{-}$generation ${ }^{*}, \downarrow$ & $\begin{array}{c}\text { Mean } \\
\text { increment in } \\
\mathrm{O}_{2}^{-} \text {release }\end{array}$ & $\begin{array}{c}\text { Sum of } \\
\text { F.MLP-induced } \\
\text { increments }\end{array}$ \\
\hline \multicolumn{5}{|l|}{ A } \\
\hline Medium & None & $0.7 \pm 0.2$ & - & \\
\hline 100 nM FMLP & None & $11.5 \pm 2.2$ & 10.8 & \\
\hline 40 n.M FMLP & None & $7.7 \pm 1.3$ & 7.0 & \\
\hline $10 \mathrm{nM} F M L P$ & None & $2.2 \pm 0.9$ & 1.5 & \\
\hline 4 nM FMLP & None & $0.6 \pm 0.3$ & -0.1 & \\
\hline B & & & $(B-D) \ddagger$ & $(A+B)$ \\
\hline Medium & $100 \mathrm{nM}$ FMLP & $10.9 \pm 1.7$ & 10.4 & 10.4 \\
\hline $100 \mathrm{nM}$ FMLP & 100 nM FMLP & $0.3 \pm 0.2$ & $0.0 \$$ & $10.8^{\sharp}$ \\
\hline 40 nM FMLP & 100 nM FMLP & $1.6 \pm 1.3$ & $1.1 \$$ & $8.1 \S$ \\
\hline $10 \mathrm{nM}$ FMLP & 100 nM FMLP & $3.5 \pm 1.1$ & $2.9 \$$ & $4.4 \S$ \\
\hline 4 n.M FMLP & 100 nM FMLP & $8.9 \pm 0.9$ & $8.5 \S$ & $8.4 \S$ \\
\hline $\mathrm{C}$ & & & $\left(C-D^{\prime}\right) \ddagger$ & \\
\hline Medium & $10 \mu \mathrm{l} / \mathrm{ml} \mathrm{C5a}$ & $8.4 \pm 1.0$ & 7.9 & \\
\hline 100 nM FMLP & $10 \mu \mathrm{l} / \mathrm{ml} \mathrm{C5a}$ & $8.3 \pm 1.0$ & 8.0 & \\
\hline 40 nM FMLP & $10 \mu \mathrm{l} / \mathrm{ml} \mathrm{C} 5 \mathrm{a}$ & $7.8 \pm 1.2$ & 7.2 & \\
\hline 10 nM FMLP & $10 \mu \mathrm{l} / \mathrm{ml} \mathrm{C5a}$ & $9.2 \pm 1.0$ & 8.6 & \\
\hline 4 nM FMLP & $10 \mu \mathrm{l} / \mathrm{ml} \mathrm{C5a}$ & $9.0 \pm 1.3$ & 8.5 & \\
\hline \multicolumn{5}{|l|}{$\mathrm{D}$ (Control) } \\
\hline Medium & Medium & $0.5 \pm 0.2$ & - & \\
\hline 100 nM FMLP & Medium & $0.3 \pm 0.2$ & - & \\
\hline 40 nM FMLP & Medium & $0.5 \pm 0.2$ & - & \\
\hline 10 nM FMLP & Medium & $0.6 \pm 0.3$ & - & \\
\hline 4 nM FMLP & Medium & $0.4 \pm 0.2$ & - & \\
\hline \multicolumn{5}{|l|}{$\mathrm{D}^{\prime}$ (Control) } \\
\hline Medium & Medium & $0.5 \pm 0.4$ & - & \\
\hline 100 n.M FMLP & Medium & $0.3 \pm 0.3$ & - & \\
\hline 40 nM FMLP & Medium & $0.6 \pm 0.2$ & - & \\
\hline 10 nM FMLP & Medium & $0.6 \pm 0.4$ & - & \\
\hline $4 \mathrm{nM} F M L P$ & Medium & $0.5 \pm 0.3$ & - & \\
\hline
\end{tabular}

$2-3 \times 10^{6}$ neutrophils were preincubated with F.MLP dilutions for 5 min at $37^{\circ} \mathrm{C}$ (sets A-D). Set $\mathrm{A}$ was assessed for ferricytochrome $c$ reduction, and $100 \mathrm{nM} \mathrm{FMLP,} 10 \mu \mathrm{l} / \mathrm{ml} \mathrm{C} 5 \mathrm{a}$, or medium was added to sets $B, C$, and D, respectively. Sets B-D were incubated for an additional $5 \mathrm{~min}$ at $37^{\circ} \mathrm{C}$, after which the supernates were analyzed.

$* \mathrm{O}_{2}^{-}$generation expressed as nanomoles of ferricytochrome $c$ reduced per $10^{6}$ neutrophils. $\ddagger$ Results represent the mean $\pm \mathrm{SD}$ of six separate experiments (sets $\mathrm{A}, \mathrm{B}$, and D) and of four separate experiments (sets $C$ and $D^{\prime}$ ) each performed in duplicate.

$\$ P$ vs. control $<0.05$.

" $P$ vs. control $>0.20$.

levels could be detected during the second 5-min incubation (Table I D).

The results of a second series of experiments testing the effects of C5a preincubation on subsequent challenge of the cells with C5a or FMLP are shown in Table II. Preincubation of the cells with $1-10 \mu \mathrm{l} / \mathrm{ml}$ C5a for $5 \mathrm{~min}$ at $37^{\circ} \mathrm{C}$ caused a dose-dependent inhibition of $\mathrm{O}_{2}^{-}$release to a second challenge by an optimal ( 10 $\mu \mathrm{l} / \mathrm{ml}$ ) concentration of C5a (Table II C). However, this C5a preincubation had no effect on subsequent $\mathrm{O}_{2}^{-}$production induced by $100 \mathrm{n} . \mathrm{M}$ F.MLP (Table II B). In contrast to FMLP-stimulated $\mathrm{O}_{2}^{-}$generation, which was complete by $5 \mathrm{~min}$, small amounts of $\mathrm{C} 5 \mathrm{a}$-induced $\mathrm{O}_{2}^{-}$release could still be measured by $10 \mathrm{~min}$ of incubation (Table II D).

Effect of calcium on FMLP-induced deactivation of superoxide generation. Table III shows the results of two experiments in which the role of calcium in FMLP- 
TABLE II

Effect of C5a Preincubation on Superoxide Generation after Subsequent Challenge with FMLP or C.5a

\begin{tabular}{|c|c|c|c|c|}
\hline \multirow[b]{2}{*}{$\begin{array}{l}\text { Preincubation } \\
\text { additions }\end{array}$} & \multirow[b]{2}{*}{$\begin{array}{l}\text { Second } \\
\text { challenge }\end{array}$} & \multirow[b]{2}{*}{$\mathrm{O}_{2}^{-}$generation* } & \multicolumn{2}{|c|}{$\begin{array}{l}\text { Mean increment in } \mathrm{O}_{2}^{-} \text {generation } \\
\text { attributed to second challenge with: }\end{array}$} \\
\hline & & & $\begin{array}{l}100 \text { nN FMLP } \\
(B-D)\end{array}$ & $\begin{array}{l}10 \mu \mathrm{l} / \mathrm{ml} \mathrm{C} 5 \mathrm{a} \\
(\mathrm{C}-\mathrm{D})\end{array}$ \\
\hline \multicolumn{5}{|l|}{ A } \\
\hline Medium & None & $0.8 \pm 0.5$ & & \\
\hline $10 \mu \mathrm{l} / \mathrm{ml} \mathrm{C5a}$ & None & $8.8 \pm 3.5$ & & \\
\hline $3.3 \mu \mathrm{l} / \mathrm{ml} \mathrm{C} 5 \mathrm{a}$ & None & $5.2 \pm 2.1$ & & \\
\hline $1.0 \mu \mathrm{l} / \mathrm{ml} \mathrm{C} 5 \mathrm{a}$ & None & $1.8 \pm 0.8$ & & \\
\hline $0.33 \mu \mathrm{l} / \mathrm{ml} \mathrm{C} 5 \mathrm{a}$ & None & $0.7 \pm 0.3$ & & \\
\hline \multicolumn{5}{|l|}{$\mathrm{B}$} \\
\hline Medium & 100 nM FMLP & $11.0 \pm 2.8$ & 10.1 & \\
\hline $10 \mu \mathrm{l} / \mathrm{ml} \mathrm{C5a}$ & $100 \cap \mathrm{M} F \mathrm{FML}$ & $13.0 \pm 2.6$ & $10.1+$ & \\
\hline $3.3 \mu \mathrm{l} / \mathrm{ml} \mathrm{C} 5 \mathrm{a}$ & 100 nM FMLP & $12.4 \pm 2.6$ & $10.2 \ddagger$ & \\
\hline $1.0 \mu \mathrm{l} / \mathrm{ml} \mathrm{C} 5 \mathrm{a}$ & 100 n.M FMLP & $11.8 \pm 3.3$ & $10.1+$ & \\
\hline $0.33 \mu \mathrm{l} / \mathrm{ml} \mathrm{C5a}$ & $100 \mathrm{nM}$ FMLP & $11.5 \pm 2.4$ & $10.4+$ & \\
\hline \multicolumn{5}{|l|}{$\mathrm{C}$} \\
\hline Medium & $10 \mu \mathrm{l} / \mathrm{ml} \mathrm{C} 5 \mathrm{a}$ & $8.5 \pm 2.4$ & & 7.6 \\
\hline $10 \mu \mathrm{l} / \mathrm{ml} \mathrm{C5a}$ & $10 \mu \mathrm{l} / \mathrm{ml} \mathrm{C5a}$ & $3.1 \pm 0.5$ & & $0.2 \S$ \\
\hline $3.3 \mu \mathrm{l} / \mathrm{ml} \mathrm{C} 5 \mathrm{a}$ & $10 \mu \mathrm{l} / \mathrm{ml} \mathrm{C5a}$ & $5.5 \pm 1.6$ & & $3.3 \$$ \\
\hline $1.0 \mu \mathrm{l} / \mathrm{ml} \mathrm{C} 5 \mathrm{a}$ & $10 \mu \mathrm{l} / \mathrm{ml} \mathrm{C} 5 \mathrm{a}$ & $8.4 \pm 1.9$ & & $6.7+$ \\
\hline $0.33 \mu \mathrm{l} / \mathrm{ml} \mathrm{C} 5 \mathrm{a}$ & $10 \mu \mathrm{l} / \mathrm{ml} \mathrm{C} 5 \mathrm{a}$ & $8.5 \pm 2.0$ & & $7.4 \ddagger$ \\
\hline \multicolumn{5}{|l|}{$\mathrm{D}$ (Control) } \\
\hline Medium & Medium & $0.9 \pm 0.6$ & & \\
\hline $10 \mu \mathrm{l} / \mathrm{ml} \mathrm{C5a}$ & Medium & $2.9 \pm 0.5$ & & \\
\hline $3.3 \mu \mathrm{l} / \mathrm{ml} \mathrm{C5a}$ & Medium & $2.2 \pm 0.7$ & & \\
\hline $1.0 \mu \mathrm{l} / \mathrm{ml} \mathrm{C5a}$ & Medium & $1.7 \pm 0.8$ & & \\
\hline $0.33 \mu \mathrm{l} / \mathrm{ml} \mathrm{C5a}$ & Medium & $1.1 \pm 0.5$ & & \\
\hline
\end{tabular}

Procedures were the same as in Table I except that cells were preincubated with C5a dilutions for $5 \mathrm{~min}$ at $37^{\circ} \mathrm{C}$.

* $\mathrm{O}_{2}^{-}$generation expressed as nanomoles of ferricytochrome $c$ reduced per $10^{6}$ neutrophils. Results represent the mean $\pm \mathrm{SD}$ of four separate experiments each performed in duplicate. In set $\mathrm{A}$, data express $\mathrm{O}_{2}^{-}$generation during preincubation only.

$\$ P$ vs. control $>0.20$.

$\S P$ vs. control $<0.05$.

induced deactivation of superoxide generation was tested. For these experiments, cells were incubated with $4-100 \mathrm{nM} \mathrm{FMLP}$ for $5 \mathrm{~min}$ at $37^{\circ} \mathrm{C}$ in the presence of $1.0 \mathrm{mM} \mathrm{CaCl}{ }_{2}$ or $1.0 \mathrm{mM}$ EDTA. The cells were then pelleted and the supernates aspirated and assayed. Without an intervening wash, the cells were resuspended in medium containing $1.0 \mathrm{mM} \mathrm{CaCl} 2,0.5$ $\mathrm{mM} \mathrm{MgCl}, 75 \mu \mathrm{M}$ ferricytochrome and $100 \mathrm{nM}$ FMLP and the reaction mixtures incubated for an additional 5 min at $37^{\circ} \mathrm{C}$. Although the presence of $1.0 \mathrm{mM}$ EDTA impaired the amount of $\mathrm{O}_{2}^{-}$generated by FMLP stimulation of the cells during the 5-min preincubation, EDTA had no effect on inhibition of the response to subsequent challenge of the cells with $100 \mathrm{nM}$ F MLP.
Effect of simultaneous additions of FMLP and C5a on the cAMP response. As previously reported, 10$100 \mathrm{nM}$ FMLP and $1-10 \mu \mathrm{l} / \mathrm{ml}$ C.5a induce a transient elevation of intracellular cAMP that peaks at $15 \mathrm{~s}$ and returns to near basal levels by 5 min (17). When either stimulus was added separately over the above stated concentration range (Fig. 2), FMLP and C5a caused a significant elevation in intracellular cAMP relative to basal levels ( $P$ vs. medium $<0.05$ ). The combination of $40 \mathrm{nM}$ FMLP plus $3.3 \mu \mathrm{l} / \mathrm{ml} \mathrm{C} 5 \mathrm{a}$, and of $10 \mathrm{nM}$ FMLP plus $1 \mu \mathrm{l} / \mathrm{ml}$ C5a evoked an additive cAMP response at $15 \mathrm{~s}$, which was greater than that seen with either stimulus alone $(P<0.05)$. Less than optimal concentrations of the two chemotactic factors, $10 \mathrm{nM}$ 
TABLE III

Effect of Calcium on FMLP-induced Deactivation of Superoxide Generation

\begin{tabular}{lccc}
\hline & \multicolumn{3}{c}{ Superoxide generation* $^{*}$} \\
\cline { 2 - 4 } $\begin{array}{c}\text { Preincubation } \\
\text { additions }\end{array}$ & $\begin{array}{c}\text { After } \\
\text { preincubation }\end{array}$ & After second challenge with \\
\cline { 3 - 4 } \cline { 3 - 4 } $100 \mathrm{nM}$ FMLP & Medium \\
\hline $\mathrm{mM} \mathrm{Ca}{ }^{2+}+$ & & & \\
Medium & 0.3 & 11.4 & 0.2 \\
$100 \mathrm{nM}$ FMLP & 11.1 & 0.2 & 0.5 \\
$40 \mathrm{nM}$ FMLP & 7.2 & 2.4 & 0.5 \\
$10 \mathrm{nM}$ FMLP & 2.3 & 4.0 & 0.2 \\
$4 \mathrm{nM}$ FMLP & 0.4 & 8.6 & 0.2 \\
$1 \mathrm{mM}$ EDTA + & & & \\
Medium & 0.3 & 12.0 & 0.2 \\
$100 \mathrm{nM}$ FMLP & 6.6 & 0.3 & 0.3 \\
$40 \mathrm{nM}$ FMLP & 2.2 & 1.9 & 0.2 \\
$10 \mathrm{nM}$ FMLP & 0.6 & 4.4 & 0.2 \\
$4 \mathrm{nM}$ FMLP & 0.2 & 9.7 & 0.2 \\
\end{tabular}

Neutrophils $\left(3 \times 10^{6}\right)$ were preincubated for $5 \mathrm{~min}$ at $37^{\circ} \mathrm{C}$ with FMLP dilutions in the presence of $1 \mathrm{mM} \mathrm{CaCl}_{2}$ or $1 \mathrm{mM}$ EDTA. The supernates were analyzed and without an intervening wash, the cells were resuspended in medium containing $1 \mathrm{mM} \mathrm{CaCl}$ and $0.5 \mathrm{mM} \mathrm{MgCl}_{2}$, together with $100 \mathrm{nM}$ FMLP or medium. After an additional incubation for $5 \mathrm{~min}$ at $37^{\circ} \mathrm{C}$, the neutrophils were pelleted and the supernates measured for $\mathrm{O}_{2}^{-}$release.

* $\mathrm{O}_{2}^{-}$generation expressed as nanomoles of ferricytochrome reduced per $10^{6}$ neutrophils. Results represent the average of two individual experiments each performed in duplicate.

FMLP and $1 \mu \mathrm{l} / \mathrm{ml} \mathrm{C5a,} \mathrm{were} \mathrm{associated} \mathrm{with} \mathrm{fully} \mathrm{addi-}$ tive responses $(P<0.05)$. The combination of the two stimuli did not appreciably prolong the time-course of the cAMP response, i.e., cAMP levels fell to control values by 5 min of incubation.

Effect of sequential additions of FMLP and C5a on the cAMP response. As shown in Table IV, preincubation of the cells with $1-10 \mu \mathrm{l} / \mathrm{ml} \mathrm{C5a}$ for $5 \mathrm{~min}$ resulted in dose-dependent inhibition of the subsequent cAMP response at $15 \mathrm{~s}$ to a second challenge with $10 \mu \mathrm{l} / \mathrm{ml} \mathrm{C5a}$ (Table IV C). However, preincubation with $1-10 \mu \mathrm{l} / \mathrm{ml}$ C5a had no effect on the subsequent cAMP response at $15 \mathrm{~s}$ to an optimal dose of $100 \mathrm{nM}$ FMLP (Table IV B).

Table IV also displays the results of a parallel series of experiments in which cells were preincubated with 10-100 nM FMLP. FMLP preincubation caused dose-dependent inhibition of the cAMP response at $15 \mathrm{~s}$ to a second stimulation with $100 \mathrm{nM}$ FMLP (Table IV $B^{\prime}$ ), but had little effect on the subsequent cAMP response to an optimal $(10 \mu \mathrm{l} / \mathrm{ml})$ C.5a dose (Table IV $\mathrm{C}^{\prime}$ ), except for depression of the cAMP increment when the cells were pretreated with $100 \mathrm{nM}$ FMLP. However, there was no difference at $1 \mathrm{~min}$ in the cAMP in- crement to C5a challenge between cells preincubated for 5 min with medium or $100 \mathrm{nM}$ FMLP (1.78 vs. 1.73 $\mathrm{pmol} / 10^{7}$ cells, $P>0.20$ ).

Effect of sequential additions of FMLP and C5a on dye-cell fluorescence. Cyanine dyes and other closely related compounds have previously been used to measure potential changes across membranes of bacteria, squid axons, erythrocytes, and tumor cells (18). The fluorescent moiety behaves as a permeant cation and optical changes result from membrane-localized dye movements. Cyanine dye absorption changes occur because of a potential-dependent partition of the dye between the membrane and the medium (19). For 3,3'dipropylthiocarbocyanine iodide, cell hyperpolarization is thought to cause uptake of dye molecules by the cells and decreased fluorescence because of the formation of dye aggregates that have reduced fluorescence. In contrast, depolarization leads to release of dye into the extracellular medium and enhanced fluorescence (19).

Continuous tracings of the fluorescence changes from a single representative donor are shown in Fig. 3, and data from several different donors are presented in Table $V$, showing the effects of preincubation with one stimulus on the subsequent response to the same or a different stimulus. For these experiments, the cells were initially stimulated and the fluorescence changes monitored continuously for $5 \mathrm{~min}$ at $37^{\circ} \mathrm{C}$. Thereafter, the second stimulus was added and the subsequent dyecell fluorescence responses followed for an additional $5 \mathrm{~min}$. The addition of $0.3-10 \mu \mathrm{l} / \mathrm{ml} \mathrm{C5}$ a caused an immediate response of increasing fluorescence, which is consistent with membrane depolarization. Peak fluorescence levels were reached within $1 \mathrm{~min}$, after which the response declined toward, but did not reach, control values by $5 \mathrm{~min}$ (Fig. 3A, 3B, and Table V). Treatment of the cells with C5a $(0.3-10 \mu \mathrm{l} / \mathrm{ml})$ caused dose-dependent inhibition of the subsequent fluorescence response to challenge with the optimal $(10 \mu \mathrm{l} /$ $\mathrm{ml}$ ) C5a dose (Fig. 3A, Table V C), but had no effect on the peak level of fluorescence achieved by the addition of $100 \mathrm{nM}$ FMLP (Fig. 3B, Table V B). However, C5a preincubation did have an effect on the subsequent FMLP-induced increment (peak FMLP-induced fluorescence minus basal level) in fluorescence. This effect was due to the fact that the fluorescence responses caused by the higher doses of C5a had not yet returned to basal levels by the end of the first 5-min incubation. Similar results were seen with FMLPi.e., treatment of the cells with 4-100 nM FMLP caused dose-dependent inhibition of the fluorescence response to subsequent challenge with $100 \mathrm{nM}$ FMLP (data not shown).

Effect of simultaneous additions of FMLP and C5a on dye-cell fluorescence. As seen with $\mathrm{O}_{2}^{-}$generation 


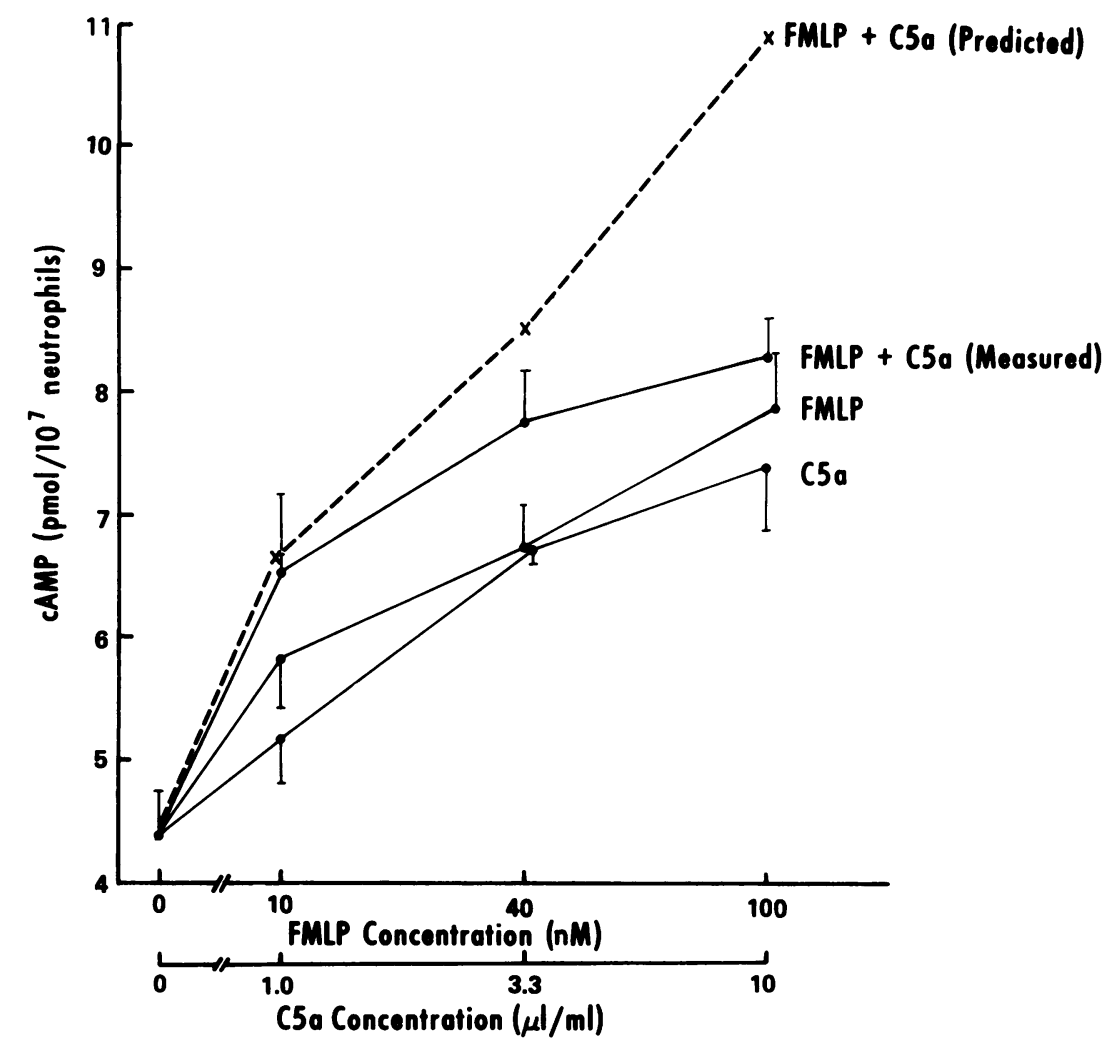

FIGURE 2 Effect of simultaneous additions of FMLP and C5a on the cAMP response. See legend to Fig. 1 except that $6-10 \times 10^{6}$ neutrophils were used for each determination and the level of cAMP determined at $15 \mathrm{~s}$. Results represent the mean \pm SD of three separate experiments each performed in triplicate.

and the cAMP response (Figs. 1 and 2), the combinations of the two simultaneously added chemotactic factors - 4-40 $\mathrm{nM}$ FMLP and $0.33-3.3 \mu \mathrm{l} / \mathrm{ml} \mathrm{C5a-}$ evoked additive peak fluorescence responses (Fig. 4) that were significantly greater $(P<0.05)$ than those fluorescence levels obtained with either stimulus alone. The separate FMLP- and C5a-induced responses were fully additive $(P<0.05)$ at concentrations ( $4 \mathrm{nM}$ FMLP plus $0.33 \mu \mathrm{l} / \mathrm{ml} \mathrm{C5a)} \mathrm{unable} \mathrm{to} \mathrm{pro-}$ mote $\mathrm{O}_{2}^{-}$release (Fig. 1). However, the combination of $100 \mathrm{nM}$ FMLP and $10 \mu \mathrm{l} / \mathrm{ml} \mathrm{C5a}$, each an optimal dose, was associated with no additive response.

\section{DISCUSSION}

FMLP and C5a have previously been shown to bind to distinct cell membrane receptors on human neutrophils $(5,6)$. The interaction of these factors with the cell has been shown to cause the biologic expressions of chemotaxis, exocytosis, and superoxide generation (20). In addition, FMLP and C5a cause membrane potential changes $(21,22)$, transient elevations of intracellular cAMP $(17,22,23)$, and influxes of $\mathrm{Na}^{+}$and $\mathrm{Ca}^{2+}(24$,
25), which have been thought to constitute, or at least reflect, early activation events, since they occur during the 15-25-s latency period before any granule enzyme release or $\mathrm{O}_{2}^{-}$generation can be detected $(17,22)$.

Preincubation of the cells with either FMLP (4-100 $\mathrm{nM})$ or C5a (1-10 $\mu \mathrm{l} / \mathrm{ml})$ caused dose-dependent inhibition of the subsequent response to an optimal dose of the same stimulus. This was shown for the fluorescence changes compatible with membrane depolarization and for the rise in cAMP, as well as for $\mathrm{O}_{2}^{-}$generation, and is analogous to the phenomenon of deactivation or desensitization noted in chemotaxis $(1-3)$ and granule enzyme release $(26,27)$. With $\mathrm{O}_{2}^{-}$release, pretreatment of the cells with an ineffective FMLP dose $(4 \mathrm{nM})$ nonetheless resulted in inhibition of the subsequent response to a second FMLP challenge. Secondly, for cells initially exposed to suboptimal FMLP doses, the sum of the increments in $\mathrm{O}_{2}^{-}$release during the two successive FMLP stimulations was less than the total $\mathrm{O}_{2}^{-}$production obtained in the presence of $100 \mathrm{nM}$ FMLP. These two lines of evidence suggest that the initial treatment of the cells with FMLP specifically deactivated the subsequent response to a second 
TABLE IV

Effect of Sequential Additions of FMLP and C5a on cAMP Response

\begin{tabular}{|c|c|c|c|c|}
\hline $\begin{array}{l}\text { Preincubation } \\
\text { additions }\end{array}$ & $\begin{array}{c}\text { Second } \\
\text { challenge }\end{array}$ & cAMP response* & \multicolumn{2}{|c|}{$\begin{array}{l}\text { Mean increment } \\
\text { in cAMP }\end{array}$} \\
\hline & \multicolumn{4}{|c|}{ pmol/10 cells } \\
\hline A & & & \multicolumn{2}{|c|}{$(A-D)$} \\
\hline Medium & None & $4.59 \pm 1.63$ & \multicolumn{2}{|c|}{-0.22} \\
\hline $10 \mu \mathrm{l} / \mathrm{ml} \mathrm{C5a}$ & None & $7.95 \pm 2.17$ & \multicolumn{2}{|r|}{3.08} \\
\hline $3.3 \mu \mathrm{l} / \mathrm{ml} \mathrm{C5a}$ & None & $7.31 \pm 2.59$ & \multicolumn{2}{|r|}{2.65} \\
\hline $1.0 \mu \mathrm{l} / \mathrm{ml} \mathrm{C5a}$ & None & $5.49 \pm 1.30$ & \multicolumn{2}{|r|}{1.21} \\
\hline B & & & \multicolumn{2}{|c|}{$(\mathrm{B}-\mathrm{D})$} \\
\hline Medium & $100 \mathrm{nM} F M L P$ & $8.67 \pm 0.61$ & 3.86 & \\
\hline $10 \mu \mathrm{l} / \mathrm{ml} \mathrm{C5a}$ & 100 nM FMLP & $8.21 \pm 1.09$ & 3.34 & $P>0.20$ \\
\hline $3.3 \mu \mathrm{l} / \mathrm{ml} \mathrm{C} 5 \mathrm{a}$ & 100 nM FMLP & $8.16 \pm 1.37$ & 3.50 & $P>0.20$ \\
\hline $1.0 \mu \mathrm{l} / \mathrm{ml} \mathrm{C5a}$ & 100 nM FMLP & $9.04 \pm 0.65$ & 4.76 & $P<0.20$ \\
\hline $\mathrm{C}$ & & & \multicolumn{2}{|c|}{$(C-D)$} \\
\hline Medium & $10 \mu \mathrm{l} / \mathrm{ml} \mathrm{C5a}$ & $7.31 \pm 0.82$ & 2.50 & \\
\hline $10 \mu \mathrm{l} / \mathrm{ml} \mathrm{C5a}$ & $10 \mu \mathrm{l} / \mathrm{ml} \mathrm{C5a}$ & $4.67 \pm 0.26$ & -0.20 & $P<0.01$ \\
\hline $3.3 \mu \mathrm{l} / \mathrm{ml} \mathrm{C5a}$ & $10 \mu \mathrm{l} / \mathrm{ml} \mathrm{C5a}$ & $6.08 \pm 0.63$ & 1.42 & $P<0.02$ \\
\hline $1.0 \mu \mathrm{l} / \mathrm{ml} \mathrm{C} 5 \mathrm{a}$ & $10 \mu \mathrm{l} / \mathrm{ml} \mathrm{C5a}$ & $7.55 \pm 1.78$ & 3.27 & $P<0.20$ \\
\hline \multicolumn{5}{|l|}{ D (control) } \\
\hline Medium & Medium & $4.81 \pm 0.98$ & & - \\
\hline $10 \mu \mathrm{l} / \mathrm{ml} \mathrm{C} 5 \mathrm{a}$ & Medium & $4.87 \pm 0.93$ & & - \\
\hline $3.3 \mu \mathrm{l} / \mathrm{ml} \mathrm{C} 5 \mathrm{a}$ & Medium & $4.66 \pm 1.09$ & & - \\
\hline $1.0 \mu \mathrm{l} / \mathrm{ml} \mathrm{C} 5 \mathrm{a}$ & Medium & $4.28 \pm 0.80$ & & - \\
\hline $\mathrm{A}^{\prime}$ & & & \multicolumn{2}{|c|}{$\left(\mathrm{A}^{\prime}-\mathrm{D}^{\prime}\right)$} \\
\hline Medium & None & $3.01 \pm 0.34$ & \multicolumn{2}{|r|}{-0.18} \\
\hline 100 nM FMLP & None & $7.59 \pm 2.16$ & \multirow{2}{*}{\multicolumn{2}{|c|}{$\begin{array}{l}3.72 \\
1.90\end{array}$}} \\
\hline $40 \mathrm{nM}$ FMLP & None & $5.62 \pm 0.47$ & \multirow{2}{*}{\multicolumn{2}{|c|}{$\begin{array}{l}1.90 \\
1.17\end{array}$}} \\
\hline 10 nM FMLP & None & $4.68 \pm 0.67$ & & \\
\hline $\mathrm{B}^{\prime}$ & & & \multicolumn{2}{|c|}{$\left(\mathbf{B}^{\prime}-\mathrm{D}^{\prime}\right)$} \\
\hline Medium & $100 \mathrm{nM} F \mathrm{FMLP}$ & $9.05 \pm 3.16$ & 5.86 & \\
\hline 100 nM FMLP & $100 \mathrm{nM}$ FMLP & $5.24 \pm 0.91$ & 1.37 & $P<0.01$ \\
\hline 40 nM FMLP & $100 \mathrm{nM}$ FMLP & $4.75 \pm 0.60$ & 1.03 & $P<0.01$ \\
\hline $10 \mathrm{nM}$ FMLP & 100 nM FMLP & $7.43 \pm 2.92$ & 3.92 & $P<0.10$ \\
\hline $\mathrm{C}^{\prime}$ & & & \multicolumn{2}{|c|}{$\left(C^{\prime}-D^{\prime}\right)$} \\
\hline Medium & $10 \mu \mathrm{l} / \mathrm{ml} \mathrm{C5a}$ & $6.85 \pm 1.42$ & 3.66 & \\
\hline 100 nM FMLP & $10 \mu \mathrm{l} / \mathrm{ml} \mathrm{C5a}$ & $5.73 \pm 1.32$ & 1.86 & $P<0.02$ \\
\hline 40 nM FMLP & $10 \mu \mathrm{l} / \mathrm{ml} \mathrm{C} 5 \mathrm{a}$ & $6.45 \pm 1.56$ & 2.73 & $P<0.20$ \\
\hline 10 nM FMLP & $10 \mu \mathrm{l} / \mathrm{ml} \mathrm{C} 5 \mathrm{a}$ & $6.43 \pm 1.85$ & 2.92 & $P>0.20$ \\
\hline \multicolumn{5}{|l|}{$\mathrm{D}^{\prime}$ (Control) } \\
\hline Medium & Medium & $3.19 \pm 0.16$ & & - \\
\hline $100 \mathrm{nM} F \mathrm{FMLP}$ & Medium & $3.87 \pm 1.20$ & & - \\
\hline $40 \mathrm{nM}$ FMLP & Medium & $3.72 \pm 1.41$ & & - \\
\hline $10 \mathrm{nM}$ FMLP & Medium & $3.51 \pm 0.26$ & & - \\
\hline
\end{tabular}

Neutrophils $\left(10^{7}\right)$ were preincubated with C5a (Sets A-D) or FMLP (Sets A'-D') dilutions. Sets $A$ and $A^{\prime}$ were assessed for the cAMP response at $15 \mathrm{~s}$ after the addition of the stimuli. Sets $\mathrm{B}, \mathrm{C}, \mathrm{D}$ and $\mathrm{B}^{\prime}, \mathrm{C}^{\prime}, \mathrm{D}^{\prime}$ were incubated for $5 \mathrm{~min}$ at $37^{\circ} \mathrm{C}$, after which $10 \mathrm{nM} F M L P, 10 \mu \mathrm{l} / \mathrm{ml} \mathrm{C5a}$, or medium, respectively, were added, and the cAMP responses measured at $15 \mathrm{~s}$.

* Results represent the mean $\pm S D$ of three separate experiments each performed in triplicate. 

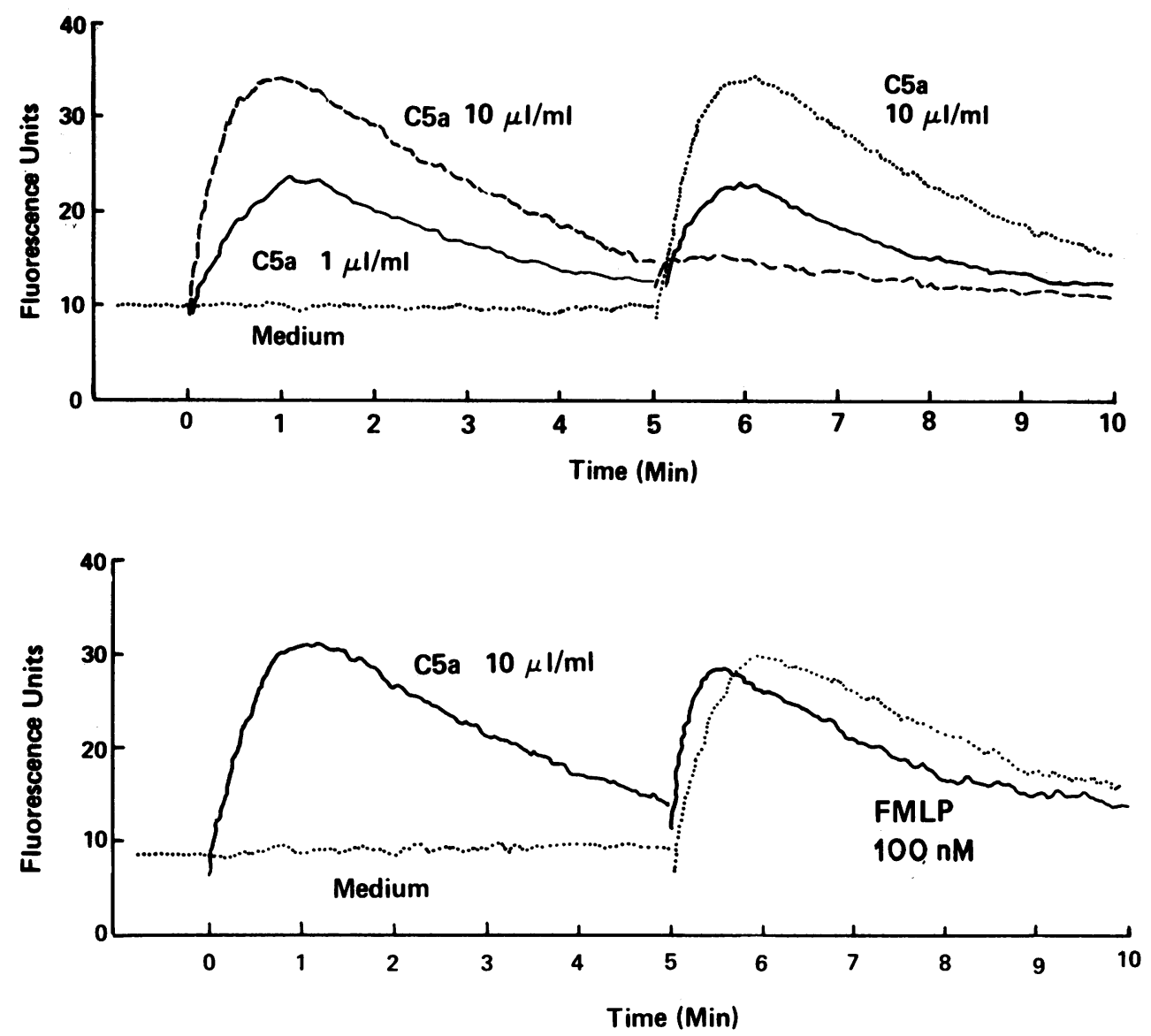

FIGURE 3 Effect of sequential additions of FMLP and C5a on dye-cell fluorescence. Neutrophils $\left(4 \times 10^{6}\right)$ were equilibrated with $1 \mu \mathrm{M} 3,3^{\prime}$-dipropylthiocarbocyanine iodide. At zero time, C5a dilutions or medium were added and the fluorescence changes recorded for $5 \mathrm{~min}$ at $37^{\circ} \mathrm{C}$. Then, either $10 \mu \mathrm{l} / \mathrm{ml} \mathrm{C5a}$ (Fig. 3A) or $100 \mathrm{nM}$ FMLP (Fig. 3B) was added and the fluorescence responses monitored for an additional $5 \mathrm{~min}$. The figures represent tracings of actual recordings from a representative donor. Total fluorescence was $47 \pm 3 \mathrm{U}$.

challenge with FMLP and that the observations reported here do not represent simple saturation of the response to a given stimulus. Receptor blockade or functional loss of receptors has been thought to be the mechanism of deactivation, and indeed, preincubation of rabbit neutrophils with FMLP has been shown to interfere with the subsequent binding of tritiated formyl-norleucyl-leucyl-phenylalanine, a closely related compound (28). However, since 10-20\% of receptor activity is still present even after exposure of the cells to large excesses of the peptide (28), it is conceivable that one or more postreceptor events may underlie, at least in part, the deactivation phenomenon. If deactivation were mediated by a later $\mathrm{Ca}^{2+}$-dependent step after receptor-ligand binding (e.g., a $\mathrm{Ca}^{2+}$ influx), then by chelating $\mathrm{Ca}^{2+}$ EDTA would be expected to impair the $\mathrm{Ca}^{2+}$ influx and thus possibly protect the cells from deactivation. The pres- ence of 1 mM EDTA together with FMLP under deactivating conditions (i.e., during the preincubation with FMLP) had no effect on inhibition of subsequent FMLP-induced $\mathrm{O}_{2}^{-}$generation occurring in the presence of $1 \mathrm{mM} \mathrm{Ca}^{2+}$. These observations are consistent with the deactivation phenomenon's mediation through receptor blockade or a functional loss of receptors, inasmuch as tritiated-FMLP binding to neutrophils occurs independently of divalent cations (9). However, one must bear in mind the possibility that calcium-independent deactivation mechanisms having nothing to do with receptors have not been precluded.

The response of the cells to sequential additions of the two chemotactic factors was also studied. Preincubation with 1-10 $\mu \mathrm{l} / \mathrm{ml} \mathrm{C5a}$ had no effect on the subsequent cAMP response or on the amount of $\mathrm{O}_{2}^{-}$generated by an optimal dose of FMLP (100 nM). Similarly, preincubation with 10-100 nM FMLP had no 
TABLE V

Effect of Preincubation with C5a on Subsequent Fluorescence

Response to FMLP or C5a

\begin{tabular}{|c|c|c|c|c|}
\hline \multirow{2}{*}{$\begin{array}{l}\text { Preincubation } \\
\text { additions } \\
(\boldsymbol{\mu} \mathrm{l} / \mathrm{ml})\end{array}$} & \multirow{2}{*}{$\begin{array}{l}\text { Second } \\
\text { challenge }\end{array}$} & \multicolumn{3}{|c|}{ Fluorescence $(F)$ units } \\
\hline & & Basal* & Peak $\downarrow$ & $\Delta \mathrm{F} \S$ \\
\hline \multicolumn{5}{|l|}{ A } \\
\hline Medium & None & $8.7 \pm 3.2$ & $8.7 \pm 3.2$ & 0.0 \\
\hline $10 \mu \mathrm{l} / \mathrm{ml} \mathrm{C5a}$ & None & $7.3 \pm 3.4$ & $28.0 \pm 4.1$ & 20.7 \\
\hline $3.3 \mu \mathrm{l} / \mathrm{ml} \mathrm{C5a}$ & None & $8.7 \pm 3.8$ & $25.3 \pm 6.1$ & 16.6 \\
\hline $1.0 \mu \mathrm{l} / \mathrm{ml} \mathrm{C5a}$ & None & $8.3 \pm 3.4$ & $18.7 \pm 5.3$ & 10.4 \\
\hline $0.3 \mu \mathrm{l} / \mathrm{ml} \mathrm{C5a}$ & None & $9.3 \pm 2.5$ & $14.0 \pm 3.1$ & 4.7 \\
\hline \multicolumn{5}{|l|}{ B } \\
\hline Medium & 100 nM FMLP & $8.0 \pm 2.6$ & $26.3 \pm 5.0$ & 18.3 \\
\hline $10 \mu \mathrm{l} / \mathrm{ml} \mathrm{C5a}$ & $100 \mathrm{nM} F \mathrm{FLP}$ & $12.3 \pm 2.3$ & $24.3 \pm 2.1$ & 12.0 \\
\hline $3.3 \mu \mathrm{l} / \mathrm{ml} \mathrm{C5a}$ & 100 nM FMLP & $12.0 \pm 4.4$ & $26.3 \pm 4.5$ & 14.3 \\
\hline $1.0 \mu \mathrm{l} / \mathrm{ml} \mathrm{C5a}$ & 100 nM FMLP & $9.7 \pm 3.1$ & $25.0 \pm 6.1$ & 15.3 \\
\hline $0.3 \mu \mathrm{l} / \mathrm{ml} \mathrm{C5a}$ & 100 nM FMLP & $8.7 \pm 3.2$ & $26.3 \pm 6.8$ & 17.6 \\
\hline \multicolumn{5}{|l|}{$\mathrm{C}$} \\
\hline Medium & $10 \mu \mathrm{l} / \mathrm{ml} \mathrm{C5a}$ & $8.0 \pm 3.4$ & $27.0 \pm 7.5$ & 19.0 \\
\hline $10 \mu \mathrm{l} / \mathrm{ml} \mathrm{C5a}$ & $10 \mu \mathrm{l} / \mathrm{ml} \mathrm{C5a}$ & $11.7 \pm 3.8$ & $12.3 \pm 4.2$ & 0.6 \\
\hline $3.3 \mu \mathrm{l} / \mathrm{ml} \mathrm{C5a}$ & $10 \mu \mathrm{l} / \mathrm{ml} \mathrm{C5a}$ & $13.0 \pm 5.0$ & $19.0 \pm 3.4$ & 6.0 \\
\hline $1.0 \mu \mathrm{l} / \mathrm{ml} \mathrm{C5a}$ & $10 \mu \mathrm{l} / \mathrm{ml} \mathrm{C5a}$ & $10.7 \pm 2.9$ & $22.3 \pm 4.2$ & 11.6 \\
\hline $0.3 \mu \mathrm{l} / \mathrm{ml} \mathrm{C5a}$ & $10 \mu \mathrm{l} / \mathrm{ml} \mathrm{C5a}$ & $9.0 \pm 2.8$ & $24.3 \pm 3.8$ & 15.3 \\
\hline
\end{tabular}

Neutrophils $\left(4 \times 10^{6}\right)$ in $3.0 \mathrm{ml}$ were equilibrated with $1 \mu \mathrm{M} 3,3^{\prime}$-dipropylthiocarbocyanine iodide. Cells were exposed to C5a dilutions and the fluorescence changes recorded for $5 \mathrm{~min}$ at $37^{\circ} \mathrm{C}$. Afterward, $100 \mathrm{nM} \mathrm{FMLP}$ or $10 \mu \mathrm{l} / \mathrm{ml} \mathrm{C5a}$ was added to sets $B$ and $C$, respectively, and the fluorescence responses observed for an additional $5 \mathrm{~min}$. Results represent the mean \pm SD of three separate experiments each performed in duplicate.

* Basal fluorescence, fluorescence level immediately before stimulation.

$\ddagger$ Peak fluorescence, peak fluorescence after stimulation.

$\S \Delta \mathrm{F}$, peak fluorescence - basal fluorescence.

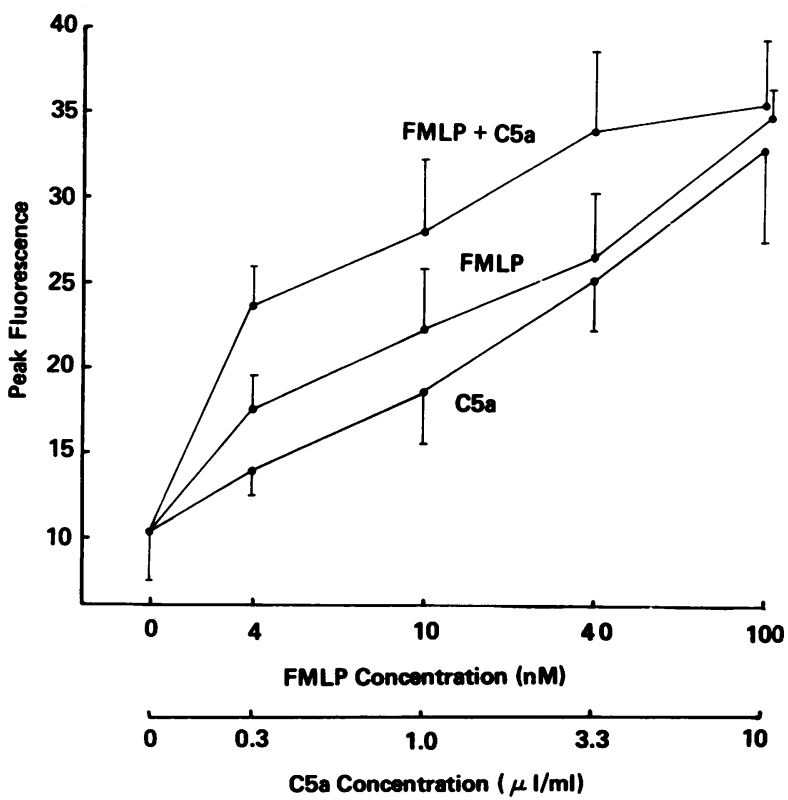

effect on the subsequent cAMP (except for apparent inhibition with $100 \mathrm{nM}$ FMLP at $15 \mathrm{~s}$, but not $1 \mathrm{~min}$ ) and $\mathrm{O}_{2}^{-}$responses to a later challenge with $10 \mu \mathrm{l} / \mathrm{ml} \mathrm{C5a}$. These experiments indicate that for these two stimuli under the conditions outlined, a phenomenon analogous to cross-deactivation or cross-desensitization does not exist for the transient rise in cAMP or for $\mathrm{O}_{2}^{-}$generation induced by FMLP and C5a. These findings parallel those reported by O'Flaherty et al. (29), wherein FMLP and C5a demonstrated selective desensitization of neutrophil aggregation in response to the chemotactic factors: after preincubation with either stimulus, subsequent challenge with the other

Figure 4 Effect of simultaneous additions of FMLP and C5a on dye-cell fluorescence. See legend to Fig. 1. Neutrophils $\left(4 \times 10^{6}\right)$ were equilibrated with $1 \mu \mathrm{M} 3,3^{\prime}$-dipropylthiocarbocyanine iodide and the peak fluorescence levels plotted after stimulation by FMLP and C5a, either separately or together. Results represent the mean $\pm S D$ of three separate experiments each performed in duplicate. Total dye fluorescence, in the absence of cells, was $52 \pm 4 \mathrm{U}$. 
stimulus evoked a normal response. Moreover, our observations parallel those of Henson et al. (26), who previously showed that preincubation of human neutrophils with C5a had no effect on subsequent enzyme release induced by casein or by zymosan particles coated with complement.

The results of experiments to test the possible crossdeactivation phenomenon for the apparent membrane depolarization response allow for alternative interpretations. On the one hand, C5a preincubation had no effect on the subsequent peak response to an optimal FMLP dose (100 nM). Should membrane depolarization itself constitute, or at least reflect, early activation events in the pathway leading to $\mathrm{O}_{2}^{-}$generation, the observations reported here are consistent with a lack of cross-deactivation of the depolarization response if the level of peak depolarization were the critical factor and/or if a threshold level of depolarization existed for cell activation. This latter hypothesis is supported by the observations that FMLP-induced depolarization and a transient increase in $\mathrm{Na}^{+}$permeability (as measured by ${ }^{22} \mathrm{Na}^{+}$fluxes) are observed at $4 \mathrm{nM}$ FMLP, a concentration at which $\mathrm{O}_{2}^{-}$generation over control levels cannot be detected (25). Alternatively, the data may be interpreted as being consistent with cross-deactivation of the depolarization response, inasmuch as the increment in the fluorescence change $(\Delta F)$ attributed to FMLP was reduced, though only modestly, by preincubation with $\mathrm{C} 5 \mathrm{a}$.

The simultaneous additions of FMLP and C5a caused enhanced fluorescent ("apparent depolarization") and cAMP responses, as well as increased $\mathrm{O}_{2}^{-}$ release relative to either stimulus alone. For each of the three parameters measured, the responses were fully additive at low stimulus concentrations and only slightly additive, if at all, at optimal FMLP and C5a doses.

These results are consistent with the hypothesis, which we favor, that FMLP and C5a, through separate receptors, utilize the same pathway of early activation events (e.g., transient $\mathrm{Ca}^{2+}$ influx and elevation in cAMP) that eventually culminates in $\mathrm{O}_{2}^{-}$generation. Alternatively, the data also support the contention that FMLP and C5a stimulation occur along parallel, completely independent pathways. Although possible, the latter supposition seems less attractive, as it implies the necessity of the cells' possessing redundant systems, a potentially wasteful duplication of effort. Finally, it is conceivable that distinct subpopulations of neutrophils exist: one subgroup reacting preferentially or exclusively with FMLP, another subgroup reacting with C5a. Against this, however, are the experiments in which FMLP and C5a were added simultaneously to the cells. If different cell populations existed, the combination of the two chemotactic factors would be expected to be fully additive over the entire range of dose responsiveness, but such was not the case.
Although $\mathrm{O}_{2}^{-}$generation induced by FMLP ceases by $5 \mathrm{~min}$, the cells are not totally refractory and are fully capable of responding to another stimulus, such as C5a, in terms of the cAMP response and $\mathrm{O}_{2}^{-}$release. These cells, however, remain unable to respond chemotactically when exposed to the second, alternate stimulus in the presence of a chemotactic gradient; i.e., there is cross-deactivation between FMLP and C5a for chemotaxis measured either in Boyden chambers or by the agarose method, as previously reported (3) and confirmed in our laboratory. ${ }^{2}$

The transient rise in cAMP induced by FMLP and $\mathrm{C} 5 \mathrm{a}$ has been suggested to represent an early activation event in the pathways leading to $\mathrm{O}_{2}^{-}$generation, exocytosis, and chemotaxis $(17,22,23)$. If true, then it is unlikely that cross-deactivation of chemotaxis is mediated by an effect on the cAMP response, since the latter cannot be cross-deactivated by FMLP and C5a. More likely, cross-deactivation of chemotaxis could be due to one or more events or processes required for chemotaxis that are irrelevant to $\mathrm{O}_{2}^{-}$generation and exocytosis of granule enzymes. An attractive candidate for this explanation is microtubule orientation and polymerization. Intact microtubule function is not required for FMLP-dependent $\mathrm{O}_{2}^{-}$release since colchicine and vinblastine, microtubule-disrupting agents, have no effect on FMLP-dependent $\mathrm{O}_{2}^{-}$production (30). Similarly, $10-100 \mu \mathrm{M}$ colchicine has been reported to have little effect on nonphagocytic degranulation and extracellular secretion of granule enzymes $(31,32)$. On the other hand, colchicine has a profound inhibitory effect on stimulated directional migration and on microtubule polymerization (4). In addition, microtubule polymerization and orientation induced by several different chemotactic factors (including FMLP) is still evident after 20 min of incubation. If chemotaxis results from integrated events requiring dynamic changes in microtubule polymerization and orientation, then a relatively prolonged or sustained effect on microtubules caused by one stimulus could account for the relative refractoriness of the cells on subsequent exposure to another chemotactic factor-i.e., cross-deactivation.

Conceivably, the biologic value of stimulus-specific deactivation and cross-deactivation could be to limit cell responses to chemotactic factors in vivo. The reason for the difference between chemotaxis and $\mathrm{O}_{2}^{-}$generation with regard to the cross-deactivation phenomenon and the significance of these observations in regard to host defense mechanisms remains to be explained.

\section{ACKNOWLEDGMENTS}

The authors wish to acknowledge the expert technical assistance of Mr. Michael Hesterberg, Mr. William Miller, Miss Betsy Goffstein, and Mr. Steven Disper, along with the secretarial skills of Mrs. Inez D. Smith and Ms. Gerlean Smith. We

\footnotetext{
${ }^{2}$ I. Spilberg. Unpublished observations.
} 
also thank Mr. John Leavitt for performing the statistical analyses.

This investigation was supported in part by the Veterans Administration, U. S. Public Health Service grant AM 19349, and an Arthritis Foundation Clinical Research Center grant.

\section{REFERENCES}

1. Ward, P. A., and E. L. Becker. 1968. The deactivation of rabbit neutrophils by chemotactic factor and the nature of the activatable esterase. J. Exp. Med. 127: 643-709.

2. Goetzl, E. J., and K. F. Austen. 1974. Active site chemotactic factors and the regulation of the human neutrophil chemotactic response. In Antibiotics and Chemotherapy. Vol. 19. Chemotaxis: Its Biology and Biochemistry. E. Sorkin and D. Platz, editors. S. Karger AG, Basel, Switzerland. 218-232.

3. Smith, C. W., J. C. Hollers, R. A. Patrick, and C. Hasset. 1979. Motility and adhesiveness in human neutrophils. Effects of chemotactic factors. J. Clin. Invest. 63: 221-229.

4. Spilberg, I., B. Mandell, and S. Hoffstein. 1979. A proposed model for chemotactic deactivation. Evidence for microtubule modulation of polymorphonuclear leukocyte chemotaxis. J. Lab. Clin. Med. 94: 361-369.

5. Williams, L. T., R. Snyderman, M. C. Pike, and R. J. Lefkowitz. 1977. Specific receptor sites for chemotactic peptides on human polymorphonuclear leukocytes. Proc. Natl. Acad. Sci. U. S. A. 74: 1204-1208.

6. Chenoweth, D. E., and T. E. Hugli. 1978. Demonstration of specific C5a receptor on intact human polymorphonuclear leukocytes. Proc. Natl. Acad. Sci. U. S. A. 75: 3343-3349.

7. Boyum, A. 1968. Isolation of mononuclear cells and granulocytes from human blood. Scan. J. Clin. Lab. Invest. 21 (Suppl. 97): 77-89.

8. Fantone, J., R. M. Senior, D. L. Kreutzer, M. Jones, and P. A. Ward. 1979. Biochemical quantitation of the chemotactic factor inactivator activity in human serum. J. Lab. Clin. Med. 93: 17-24.

9. Simchowitz, L., and I. Spilberg. 1979. Generation of superoxide radicals by human peripheral neutrophils activated by chemotactic factor. Evidence for the role of calcium. J. Lab. Clin. Med. 93: 583-593.

10. Van Gelder, B. F., and E. C. Slater. 1962. The extinction coefficient of cytochrome c. Biochim. Biophys. Acta. 58: 593-595.

11. Hatch, G. E., W. K. Nichols, and H. R. Hill. 1978. A simplified procedure for cyclic nucleotide radioimmunoassay and its application to human blood leukocytes. J. Immunol. Methods. 19: 301-308.

12. Atkinson, J. P., A. Weiss, M. Ito, J. Kelly, and C. W. Parker. 1979. Effects of ascorbic acid and sodium ascorbate on nucleotide metabolism in human lymphocytes. J. Cyclic Nucleotide Res. 5: 107-123.

13. Harper, J., and G. Brooker. 1975. Femtomole sensitive radioimmunoassay for cyclic AMP and cyclic GMP after $2^{\prime} 0$ acetylation by acetic anhydride in aqueous solution. J. Cyclic Nucleotide Res. 1: 207-214.

14. Steiner, A. L, C. W. Parker, and D. M. Kipnis. 1972. Radioimmunoassay for cyclic nucleotides. J. Biol. Chem. 247: $1106-1113$.

15. Atkinson, J. P., J. P. Kelly, A. Weiss, H. J. Wedner, and C. W. Parker. 1978. Enhanced intracellular cGMP concentrations and lectin-induced lymphocyte transformation. $J$. Immunol. 121: 2282-2291.

16. Edwards, A. L. 1967. The $t$ test for means. In Statistical Methods. Holt, Rinehart, and Winston, New York. 2nd edition. 200-225.

17. Simchowitz, L., L. C. Fischbein, I. Spilberg, and J. P.
Atkinson. 1980. Induction of a transient elevation in intracellular levels of adenosine $3^{\prime}, 5^{\prime}$-cyclic monosphate by chemotactic factors: an early event in human neutrophil activation. J. Immunol. 124: 1482-1491.

18. Waggoner, A. 1976. Optical probes of membrane potential. J. Membrane Biol. 27: 317-334.

19. Sims, P. J., A. S. Waggoner, C. H. Wang, and J. F. Hoffman. 1974. Studies on the mechanism by which cyanine dyes measure membrane potential in red blood cells and phosphatidylcholine vesicles. Biochemistry 13: 33153330 .

20. Henson, P. M., M. H. Ginsberg, and D. C. Morrison. 1978. Mechanisms of mediator release by inflammatory cells. In Membrane Fusion. G. Poste and G. L. Nicholson, editors. Elsevier/North-Holland, Amsterdam. 407-508.

21. Seligmann, B., E. K. Gallin, D. L. Martin, W. Shain, and J. I. Gallin. 1977. Evidence for membrane potential changes in human polymorphonuclear leukocytes during exposure to the chemotactic factor f-met-leu-phe as measured with the fluorescent dye dipentyloxacarbocyanine.J. Cell Biol. 75: 103a. (Abstr.)

22. Smolen, J. F., H. M. Korchak, and G. Weissmann. 1979. The first minute of granulocyte stimulation: changes in cyclic nucleotide levels are not the first signal. Clin. Res. 27: 307a. (Abstr.)

23. Jackowksi, S., and R. I. Sha'afi. 1979. Response of adenosine cyclic $3^{\prime} 5^{\prime}$-monophosphate level in rabbit neutrophils to the chemotactic peptide formyl-methionyl-leucylphenylalanine. Mol. Pharmacol. 16: 473-481.

24. Naccache, P. H., H. J. Showell, E. L. Becker, and R. I. Sha'afi. 1977. Changes in ionic movements across rabbit polymorphonuclear leukocyte membranes during lysosomal enzyme release. Possible ionic basis for lysosomal enzyme release. J. Cell Biol. 75: 635-649.

25. Simchowitz, L., and I. Spilberg. 1979. Chemotactic factorinduced generation of superoxide radicals by human neutrophils: evidence for the role of sodium.J. Immunol. 123: 2428-2435.

26. Henson, P. M., B. Zanolari, N. A. Schwartzman, and S. R. Hong. 1978. Intracellular control of human neutrophil secretion. I. C5a-induced stimulus-specific desensitization and the effects of cytochalasin B. J. Immunol. 121: 851-855.

27. Showell, H. J., D. Williams, E. L. Becker, P. H. Naccache, and R. Sha'afi. 1979. Desensitization and deactivation of the secretory responsiveness of rabbit neutrophils induced by the chemotactic peptide, formyl-methionylleucyl-phenylalanine. J. Reticuloendothel. Soc. 25: 139150 .

28. Vitkauskas, G., H. J. Showell, and E. L. Becker. 1980. Specific binding of synthetic chemotactic peptides to rabbit peritoneal neutrophils: effects on dissociability of bound peptide, receptor activity and subsequent biologic responsiveness (deactivation). Mol. Immunol. 17: 171186.

29. O'Flaherty, J. T., D. L. Kreutzer, H. J. Showell, G. Vitkauskas, E. L. Becker, and P. A. Ward. 1979. Selective neutrophil desensitization to chemotactic factors. J. Cell Biol. 80: 564-572.

30. Simchowitz, L., J. Mehta, and I. Spilberg. 1979. Chemotactic factor-induced generation of superoxide radicals by human neutrophils. Effect of metabolic inhibitors and antiinflammatory drugs. Arthritis Rheum. 22: 755-763.

31. Henson, P. M. 1972. Pathologic mechanisms in neutrophil-mediated injury. Am. J. Pathol. 68: 593-606.

32. Hawkins, D. 1974. Neutrophilic leukocytes in immunologic reactions in vitro. III. Pharmacologic modulation of lysosomal constituent release. Clin. Immunol. Immunopathol. 2: 141-152. 